\title{
Stress Faced by Homemakers Due to Online Mode of Education and Work from Home by Family Members During Covid-19 Pandemic
}

\author{
Harish Kumar S. Purohit ${ }^{1}$, Tejashree Deshmukh ${ }^{2}$ and Jigar Patel ${ }^{2}$ \\ ${ }^{1}$ Parle Tilak Vidyalaya Association's Institute of Management \\ (Affiliated to University of Mumbai), Maharashtra, India \\ ${ }^{2}$ Academics, PTVA's Institute of Management, Maharashtra, India
}

\section{ABSTRACT}

COVID-19 has caused immense psychological and physical stress to almost everyone in the world. It has drastically changed the way people live and work. It has changed the way people communicate with each other and it has also changed the way people perceive different situations, relationships and things. Though a lot is talked about, discussed and researched upon the effects of COVID-19 on work-life balance, education sector, financial issues, issues arising from Work from Home for employees, health concerns about senior citizens and people with co-morbidities, the stress faced by homemakers due to online mode of education and work from home by family members during COVID-19 pandemic, is an area that remains relatively neglected. Family members being at home for most of the time of the day, is a new phenomenon for these homemakers. It is not very easy for them to deal with this new situation emotionally and physically. It means a lot of compromises are expected to be made by the homemaker in terms of time, energy and privacy, as she is most often taken for granted by our male dominated society. She has lost the only ME time that she used to get during the day while her family members were out attending their daily chores. Being at home for most of the time by family members has also increased her work at home as it is assumed by most of the family members that while they are busy attending to their professional and educational commitments, she is relatively free to take care of all their needs. This research paper tries to explore the stress faced by these homemakers due to such situations arising out of COVID-19.

KEY WORDS: STRESS, HOMEMAKER, HOUSEWIFE, ONLINE MODE OF EDUCATION, WORK FROM HOME, COVID-19 PANDEMIC

\section{INTRODUCTION}

For every family, a lady of the house is the backbone on whom the entire family relies for almost all the daily chores. This holds especially true for the homemakers

Biosc Biotech Res Comm P-ISSN: 0974-6455 E-ISSN: 2321-4007

\section{crossef}

Identifiers and Pagination

Year: 2021 Vol: 14 No (5) Special Issue

Pages: 61-66

This is an open access article under Creative

Commons License Attribn 4.0 Intl (CC-BY).

DOI: $h t t p: / / d x . d o i . o r g / 10.21786 / b b r c / 14.5 / 13$ (many times referred to as "Housewife") whose contribution to the family remains unnoticed most of the times and who are taken for granted. COVID-19 has forced almost everyone to lock themselves indoors. It impacted every aspect of human life, be it social, economic, psychological or cultural. Though the lockdown and quarantine period made things really difficult for everyone, it made things worse especially for home- makers who have the most burden when it comes to light the responsibility part on the home front, from household chores to cooking different dishes and meeting the demands of the family members, to share their mobile phone, electronic gadgets, room and "MI" time with the family members who are

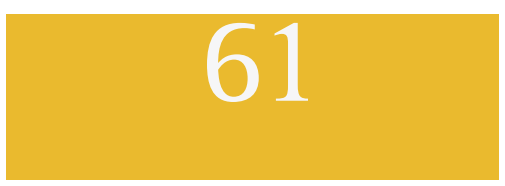


wither working from home and/or are attending online education courses. (Manocha, 2020).

Though there is a lot discussed and researched about the adverse effects on the Work-Life balance of the working women, there is very little focus on the stress faced by the homemakers during COVID pandemic due to Work from Home and the online mode of education by the family members. The patriarchal Indian society traditionally takes the homemakers for granted and it is almost always assumed that those who are required to go outside the home for the purpose of earning money and/or education, must be given a preference over her when it comes to making things available. It is also believed that the homemaker being at home all the time, needs to tend to the needs and requirements of the family and hence, put their demands before her. This mindset continues during the COVID-19 pandemic and has resulted in additional stress for the homemakers who are required to shared their time, gadgets including mobile phones and space with other family members as per their requirement, in addition to the demands regarding preference of food and frequency of serving it as well as other demands including making all those things available to the other family members that they need for their work and/or online classes.

Need of the Study: The only time that is generally available to the homemaker for herself, is the time when her family members are away from attending their work duties and/or school/college/tuitions, etc. That is the time when she can be herself for a while and spend it for relaxation, connecting with the people close to her, pursuing some hobby, etc. This is generally the only "ME" time available to her. However, COVID 19 has led to encroachment on her "ME" time now. As almost every family member is at home throughout the day, the homemakers are busy for the entire day attending and meeting the demands of the family members. If the house is small and the monetary resources are very limited, then it is the homemaker who is required to make the compromises in terms of sharing the space and other resources including her mobile phone, other electronic gadgets, etc. The remote control of the television is constantly away from her so the shows she used to watch for her entertainment before COVID-19, can't be watched by her now to unwind herself.

All these things and many others have added to the physical and psychological stress of the homemakers. To have a better understanding about the kind of stress faced by the homemakers due to COVID 19, it is required to understand the factors that were vital to a homemaker to distress herself prior to COVID 19 and then to compare these factors in the context of Work from Home and/or online education mode adopted by the family members during the Pandemic.

Literature Review: As described in her thesis on "Identification of Young Homemakers' Management Problems Related to Resource Limitations" by Koza M. in 1974, "the homemakers appeared to place a high value on their dual roles as wife and mother and were willing to try new ideas to enhance their roles." It seems that what held true long back in 1970s, is still valid in the contemporary context. In a research study "The Happy Homemaker?: Married Women's Well-Being in Cross-National Perspective”, Treas J. et al (2011) found across 28 countries, that traditionally homemakers have statistically significant and robust, happiness advantage when compared to full-time working wives. It showed that their personal satisfaction levels were better than the working women who had to juggle between their personal and professional commitments.

However, the research done during the COVID 19 pandemic by Cofey C., et al (2020) reveal that the unpaid household work is physically taxing and time consuming. Especially during the COVID-19 pandemic, such unpaid work of homemakers which is increased substantially due to lockdown and problems arising out of it, including non-availability of the maids, family members being at home for most of the time, is taking away most of their time and has resulted in these homemakers having very little or no time for themselves, restrictions on the movement in the house, very little or no place for themselves in the house, very little contact with the near and dear ones besides the family members, very little or no time to pursue a hobby, etc.

COVID-19 pandemic has affected women differently than men especially when it comes to the increased burden of unpaid work. Patriarchal Indian society always made the women work disproportionately as compared to men on the household chores which are not rewarded monetarily. The lockdown due to COVID-19 has further added to these unpaid tasks required to be carried out by women due to absence of the domestic staff to carry out washing, cleaning, cooking, etc. As the outside options with respect to getting the food, availing the services for the purpose of laundry, getting the groceries and vegetables delivered at home, etc. are not available, even these tasks are added to the daily chores expected to be done by the lady of the house.

This has resulted in additional work and though almost every family member is at home attending to his/her job duties and/or education, it is expected that the homemaker who apparently does not have any productive work to do as perceived by the traditional Indian society, must take care of all these addition unpaid domestic tasks. She is expected to cook more often and fancy cuisine in addition to serving the family members throughout the day as the outside food is less available and is not advisable to consume. The homemaker on an average is working 70 hours a week now on these unpaid domestic tasks, a good amount of part was done by the domestic helps before the pandemic. (Chauhan, 2020).

In a study on a "Qualitative Research On Homemakers For Impact Analysis Of COVID-19 On The Psychological State Throughout Lockdown In Jabalpur City" (Manocha A., et al, 2020) it was found that as homemakers are spending more time on the household chores due to 
constant presence of the family members at home and no domestic help available to share their burden of these unpaid household tasks, they get very little or no time to pursue their hobbies or to get connected with the people to whom they can speak freely and ventilate, these homemakers are getting stressed both physically and psychologically more than before.

\section{Objectives}

1. To study whether there is any change in the family support received by housewives post implementation of COVID-19 induced lockdown

2. To study whether there is any change in the personal life satisfaction of housewives post implementation of COVID-19 induced lockdown

3. To study whether there is any change in the access to mobile phones available to the housewives post implementation of COVID-19 induced lockdown

4. To study whether there is any change in the access to the television available to the housewives post implementation of COVID-19 induced lockdown

5. To study whether there is any change in the frequency of the contact made by the housewives with their friends' post implementation of COVID-19 induced lockdown

6. To study whether there is any change in the frequency of the contact made by the housewives with their relatives post implementation of COVID19 induced lockdown

7. To study whether there is any change in the personal life expectations of the housewives post implementation of COVID-19 induced lockdown

\section{RESEARCH METHODOLOGY}

A structured questionnaire having 25 questions was prepared for the purpose of the study. The first five questions were designed to capture the demographics of the respondents. The remaining 20 questions were divided into two parts and they were designed such that the respondents have to respond to them separately. The first part was designed to capture the experiences of the housewives before the COVID induced lockdown was implemented. The second part of the questionnaire was focused on capturing the responses of the housewives after the lockdown was implemented.

The questionnaire was sent to $200+$ respondents online and 18 respondents offline of which 126 respondents answered the questionnaire online and 18 answered it offline, and all of the collected responses were usable for the statistical analysis. Though the researchers had originally planned to conduct the survey offline inperson, the COVID-19 induced lockdown and social distancing limited the feasibility of the same. The 18 responses were gathered because of easily accessibility to them near the researcher's place of residence. The researcher later adopted online distribution of the questionnaire via mediums such as e-mail and instant messaging to the contacts. The sampling method used for this study was convenience sampling. The sample size for this study is 144 housewives as respondents, all the residents of Greater Mumbai.

The characteristics of the sample are illustrated in the following tables.

Table 1. Age of the respondents $\mathrm{ft}$ number of their children staying with them.

\begin{tabular}{|c|c|c|c|c|c|c|c|c|c|}
\hline & & \multicolumn{7}{|c|}{ Age of the Respondents } & \multirow[t]{2}{*}{ Total } \\
\hline & & $18-25$ & $26-30$ & $31-35$ & $36-40$ & $41-45$ & $46-50$ & Above 50 & \\
\hline \multirow{4}{*}{$\begin{array}{l}\text { Number of } \\
\text { Children }\end{array}$} & More than three & 0 & 0 & 0 & 0 & 2 & 0 & 0 & 2 \\
\hline & None & 2 & 0 & 2 & 0 & 0 & 2 & 2 & 8 \\
\hline & One & 0 & 4 & 10 & 26 & 16 & 8 & 14 & 78 \\
\hline & Two & 0 & 0 & 4 & 16 & 6 & 26 & 4 & 56 \\
\hline Total & 2 & 4 & 16 & 42 & 24 & 36 & 20 & 144 & \\
\hline
\end{tabular}

Table 2. Age of the respondents and the type of family they are staying in.

\begin{tabular}{|c|c|c|c|c|c|c|c|c|c|}
\hline & & \multicolumn{7}{|c|}{ Age of the Respondents } & \multirow[t]{2}{*}{ Total } \\
\hline & & $18-25$ & $26-30$ & $31-35$ & $36-40$ & $41-45$ & $46-50$ & Above 50 & \\
\hline \multirow{2}{*}{$\begin{array}{l}\text { Family } \\
\text { Type }\end{array}$} & Joint Family & 2 & 2 & 8 & 14 & 8 & 6 & 2 & 42 \\
\hline & Nuclear Family & 0 & 2 & 8 & 28 & 16 & 30 & 18 & 102 \\
\hline Total & 2 & 4 & 16 & 42 & 24 & 36 & 20 & 144 & \\
\hline
\end{tabular}

The instrument prepared for this study had 20 items.

items was determined using Cronbach's $\alpha$.

Reliability of the instrument: The reliability of the non-

The result of the same is as below: demographic part of the questionnaire comprising 20 
Table 3. Highest qualifications of the respondents

\begin{tabular}{|c|c|c|c|c|c|c|c|c|c|}
\hline & & \multicolumn{7}{|c|}{ Age of the Respondents } & \multirow[t]{2}{*}{ Total } \\
\hline & & $18-25$ & $26-30$ & $31-35$ & $36-40$ & $41-45$ & $46-50$ & Above 50 & \\
\hline \multirow{4}{*}{$\begin{array}{l}\text { Highest } \\
\text { Quali- } \\
\text { fication }\end{array}$} & $\begin{array}{l}\text { Post Graduate } \\
\text { \&t Above }\end{array}$ & 0 & 2 & 10 & 24 & 8 & 10 & 10 & 64 \\
\hline & Graduate & 0 & 2 & 6 & 16 & 12 & 20 & 10 & 66 \\
\hline & $\begin{array}{c}\text { Higher Secondary } \\
\text { Pass }\end{array}$ & 2 & 0 & 0 & 2 & 2 & 2 & 0 & 8 \\
\hline & $\begin{array}{l}\text { Upto Higher } \\
\text { Secondary }\end{array}$ & 0 & 0 & 0 & 0 & 2 & 4 & 0 & 6 \\
\hline Total & & 2 & 4 & 16 & 42 & 24 & 36 & 20 & 144 \\
\hline
\end{tabular}

Table 4. Annual Family Income of the Respondents

\begin{tabular}{|c|c|c|c|c|c|c|c|c|c|}
\hline & & \multicolumn{7}{|c|}{ Age of the Respondents } & \multirow[t]{2}{*}{ Total } \\
\hline & & $18-25$ & $26-30$ & $31-35$ & $36-40$ & $41-45$ & $46-50$ & Above 50 & \\
\hline \multirow{4}{*}{$\begin{array}{l}\text { Annual } \\
\text { Family } \\
\text { Income }\end{array}$} & $\begin{array}{c}\text { Rs. } 0 \text { - } \\
\text { Rs. } 500,000\end{array}$ & 2 & 4 & 4 & 12 & 2 & 6 & 8 & 38 \\
\hline & $\begin{array}{l}\text { Rs. } 500,000 \\
\text { - Rs. } 10,00,000\end{array}$ & 0 & 0 & 2 & 6 & 12 & 10 & 6 & 36 \\
\hline & $\begin{array}{l}\text { Rs. } 10,00,000 \\
\text { - Rs. } 15,00,000\end{array}$ & 0 & 0 & 6 & 0 & 10 & 10 & 2 & 28 \\
\hline & $\begin{array}{c}\text { Above } \\
\text { Rs. } 15,00,000\end{array}$ & 0 & 0 & 4 & 24 & 0 & 10 & 4 & 42 \\
\hline Total & & 2 & 4 & 16 & 42 & 24 & 36 & 20 & 144 \\
\hline
\end{tabular}

Table 5. Factors and number of items in the questionnaire

\begin{tabular}{|l|c|c|}
\multirow{2}{*}{ Factor } & \multicolumn{2}{|c|}{ No. of items } \\
\cline { 2 - 3 } & $\begin{array}{c}\text { Before } \\
\text { lockdown }\end{array}$ & $\begin{array}{c}\text { Post } \\
\text { lockdown }\end{array}$ \\
\hline Family Support & 2 & 2 \\
\hline Personal Life Satisfaction & 2 & 2 \\
\hline Access to mobile phone & 1 & 1 \\
\hline Access to television & 1 & 1 \\
\hline Contact with friends & 1 & 1 \\
\hline Contact with relatives & 1 & 1 \\
\hline Personal Life Expectations & 2 & 2 \\
\hline
\end{tabular}

Table 6. Reliability of the instrument

\begin{tabular}{|l|c|}
\hline Cronbach's Alpha & Number of Items \\
\hline .824 & 20 \\
\hline
\end{tabular}

In order to find whether there was any significant difference in the lives of the respondent housewives before and after the COVID induced lockdown was imposed, the researchers initially considered using a paired sample t-test as the same respondent housewives were administered the questionnaire both the times. However, the use of a paired t-test mandates the assumption that the differences between the matched pair should be normally distributed. In order to test for normality of the differences between the pairs, Kolmogorov-Smirnov Test and Shapiro-Wilk Test were conducted using SPSS, and the results of which are given in the following table.

The researchers then proceeded with Wilcoxon Signed Ranks Tests to test the following hypotheses

\section{Hypothesis 01:}

H1: There is no significant change in the family support received by the housewives after the COVID-19 induced lockdown was implemented

The Wilcoxon Signed Ranks Test yielded the following result:

The Wilcoxon Signed Rank Test revealed that there is statistically significant change in the family support received by the housewives after the COVID-19 induced lockdown was implemented, $\mathrm{z}=-7.885$ and $\mathrm{p}=0.000$ $(<0.05)$. Hence we reject $\mathrm{H} 1$.

Hypothesis 02:

H2: There is no significant change in the personal life expectations by the housewives after the COVID-19 induced lockdown was implemented 
The Wilcoxon Signed Ranks Test yielded the following result:

The Wilcoxon Signed Rank Test revealed that there is statistically significant change in the personal life expectations by the housewives after the COVID 19 induced lockdown was implemented, $\mathrm{z}=-8.744$ and $\mathrm{p}$
$=0.000(<0.05)$. Hence we reject $\mathrm{H} 2$.

Hypothesis 03:

H3:There is no significant change in the access to the mobile phones available to the housewives after the COVID-19 induced lockdown was implemented

The Wilcoxon Signed Ranks Test yielded the following result:

Table 7. Tests for Normality

Tests of Normality

\begin{tabular}{l|c|c|c|c|c|c|c|c|}
\cline { 2 - 9 } & \multicolumn{4}{c|}{ Kolmogorov-Smirnova } & \multicolumn{4}{c|}{ Shapiro-Wilk } \\
\cline { 2 - 9 } & Statistic & df & Sig. & Conclusion & Statistic & df & Sig. & Conclusion \\
\hline $\begin{array}{l}\text { DIFFERENCE_ } \\
\begin{array}{l}\text { FAMILY_ } \\
\text { SUPPORT }\end{array}\end{array}$ & .191 & 144 & .000 & $\begin{array}{c}\text { Not normally } \\
\text { distributed }\end{array}$ & .941 & 144 & .000 & $\begin{array}{c}\text { Not normally } \\
\text { distributed }\end{array}$ \\
\hline $\begin{array}{l}\text { DIFFERENCE_ } \\
\text { PERSONAL_LIFE } \\
\text { _SATISFACTION }\end{array}$ & .119 & 144 & .000 & $\begin{array}{c}\text { Not normally } \\
\text { distributed }\end{array}$ & .960 & 144 & .000 & $\begin{array}{c}\text { Not normally } \\
\text { distributed }\end{array}$ \\
\hline $\begin{array}{l}\text { DIFFERENCE_ } \\
\text { MOBILE_ } \\
\text { ACCESS }\end{array}$ & .237 & 144 & .000 & $\begin{array}{c}\text { Not normally } \\
\text { distributed }\end{array}$ & .870 & 144 & .000 & $\begin{array}{c}\text { Not normally } \\
\text { distributed }\end{array}$ \\
\hline $\begin{array}{l}\text { DIFFERENCE_ } \\
\text { TV_ACCESS }\end{array}$ & .249 & 144 & .000 & $\begin{array}{c}\text { Not normally } \\
\text { distributed }\end{array}$ & .857 & 144 & .000 & $\begin{array}{c}\text { Not normally } \\
\text { distributed }\end{array}$ \\
\hline $\begin{array}{l}\text { DIFFERENCE_ } \\
\text { FRIENDS }\end{array}$ & .218 & 144 & .000 & $\begin{array}{c}\text { Not normally } \\
\text { distributed }\end{array}$ & .909 & 144 & .000 & $\begin{array}{c}\text { Not normally } \\
\text { distributed }\end{array}$ \\
\hline $\begin{array}{l}\text { DIFFERENCE_ } \\
\text { RELATIVES }\end{array}$ & .269 & 144 & .000 & $\begin{array}{c}\text { Not normally } \\
\text { distributed }\end{array}$ & .879 & 144 & .000 & $\begin{array}{c}\text { Not normally } \\
\text { distributed }\end{array}$ \\
\hline $\begin{array}{l}\text { DIFFERENCE_ } \\
\text { PERSONAL_LIFE } \\
\text { EXXPECTATION }\end{array}$ & .150 & 144 & .000 & $\begin{array}{c}\text { Not normally } \\
\text { distributed }\end{array}$ & .939 & 144 & .000 & $\begin{array}{c}\text { Not normally } \\
\text { distributed }\end{array}$ \\
\hline
\end{tabular}

a. Lilliefors Significance Correction

\begin{tabular}{|c|c|}
\hline & $\begin{array}{l}\text { FMLY_SUPPORT_AL } \\
\text { - FMLY_SUPPORT_BL }\end{array}$ \\
\hline $\mathrm{Z}$ & $-7.885^{\mathrm{a}}$ \\
\hline Asymp. Sig. (2-tailed) & .000 \\
\hline a. Based on positive ranks. & \\
\hline
\end{tabular}

PRSNL_LIFE_SATSFCTN_AL

- PRSNL_LIFE_SATSFCTN_BL

\begin{tabular}{|l|c|}
\hline $\mathrm{Z}$ & $-8.744^{\mathrm{a}}$ \\
\hline Asymp. Sig. (2-tailed) & .000 \\
\hline a. Based on positive ranks. & \\
\hline
\end{tabular}

The Wilcoxon Signed Rank Test revealed that there is statistically significant change in access to their mobile phones available to the housewives after the COVID 19 induced lockdown was implemented, $\mathrm{z}=-3.544$ and $\mathrm{p}$ $=0.000(<0.05)$. Hence we reject H3.

\section{Hypothesis 04:}

H4: There is no significant change in the access to the TV available to the housewives after the COVID-19 induced lockdown was implemented

The Wilcoxon Signed Ranks Test yielded the following result:

\begin{tabular}{|l|c|}
\hline \multicolumn{2}{|c|}{$\begin{array}{c}\text { MOBILE_ACCESS_AL - } \\
\text { MOBILE_ACCESS_BL }\end{array}$} \\
\hline Z & $-3.544^{\mathrm{a}}$ \\
\hline Asymp. Sig. (2-tailed) & .000 \\
\hline a. Based on positive ranks. & TV_ACCESS_AL \\
\hline \multicolumn{2}{|c|}{- TV_ACCESS_BL } \\
\hline \multicolumn{2}{|c|}{-3.738a } \\
\hline Z & .000 \\
\hline Asymp. Sig. (2-tailed) & \\
\hline a. Based on positive ranks. & \\
\hline
\end{tabular}


The Wilcoxon Signed Rank Test revealed that there is statistically significant change in access to their mobile phones available to the housewives after the COVID19 induced lockdown was implemented, $\mathrm{z}=-3.544$ and $\mathrm{p}$ $=0.000(<0.05)$. Hence we reject $\mathrm{H} 4$.

Hypothesis 05:

H5: There is no significant change in the frequency of the contact with friends maintained by housewives after the COVID19 induced lockdown was implemented The Wilcoxon Signed Ranks Test yielded the following result:

\begin{tabular}{|l|c|}
\hline \multicolumn{1}{|c|}{} & $\begin{array}{c}\text { FRIENDS_AL - } \\
\text { FRIENDS_BL }\end{array}$ \\
\hline Z & $-6.792 \mathrm{a}$ \\
\hline Asymp. Sig. (2-tailed) & .000 \\
\hline a. Based on positive ranks. & \\
\hline
\end{tabular}

The Wilcoxon Signed Rank Test revealed that there is statistically significant change in the frequency of the contact with friends maintained by housewives after the COVID-19 induced lockdown was implemented, $\mathrm{z}=$ -6.792 and $p=0.000(<0.05)$. Hence we reject H5.

Hypothesis 06:

H6: There is no significant change in the frequency of the contact with relatives maintained by housewives after the COVID19 induced lockdown was implemented The Wilcoxon Signed Ranks Test yielded the following result:

\begin{tabular}{|l|c|}
\hline \multicolumn{2}{|c|}{$\begin{array}{c}\text { RELATIVES_AL - } \\
\text { RELATIVES_BL }\end{array}$} \\
\hline Z & $-6.110 \mathrm{a}$ \\
\hline Asymp. Sig. (2-tailed) & .000 \\
\hline a. Based on positive ranks. & \\
\hline
\end{tabular}

The Wilcoxon Signed Rank Test revealed that there is statistically significant change in the frequency of the contact with relatives maintained by housewives after the COVID19 induced lockdown was implemented, $\mathrm{z}=$ -6.110 and $p=0.000(<0.05)$. Hence we reject H6.

\section{Hypothesis 07:}

H7:There is no significant change in the personal life expectations of the housewives after the COVID19 induced lockdown was implemented

The Wilcoxon Signed Ranks Test yielded the following result:

\begin{tabular}{|l|c|}
\hline \multicolumn{2}{|c|}{$\begin{array}{r}\text { PRSNL_LIFE_EXPTN_AL - } \\
\text { PRSNL_LIFE_EXPTN_BL }\end{array}$} \\
\hline Z & $-6.280 \mathrm{a}$ \\
\hline Asymp. Sig. (2-tailed) & .000 \\
\hline a. Based on positive ranks. & \\
\hline
\end{tabular}

The Wilcoxon Signed Rank Test revealed that there is statistically significant change in the personal life expectations of the housewives after the COVID19 induced lockdown was implemented, $\mathrm{z}=-6.280$ and $\mathrm{p}$ $=0.000(<0.05)$. Hence we reject H7.

\section{CONCLUSION}

From the above tests it is evident that the lives of the housewives have changed significantly post implementation of the COVID-19 induced lockdown. The examination of the pre-lockdown and post-lockdown median values of the factors show significant reduction in their value. The lockdown, and the trend of work from home and online education which followed the lockdown, has significantly affected the housewives' personal life satisfaction and personal life expectations. Moreover, this lockdown has significantly affected their access to their own mobile phones and television. The frequency of meeting their friends and relatives have also reduced significantly making the housewives confined to their homes with little access to entertainment and recreation while their husband and children pursue their work and studies from home.

\section{REFERENCES}

Chauhan, P. Gendering COVID-19: Impact of the Pandemic on Women's Burden of Unpaid Work in India. Gend. Issues (2020). https://doi.org/10.1007/s12147020-09269-w

Cofey, C., Revollo, P. E., Harvey, R., Lawson, M., Butt, A. P., Piaget, K., et al. (2020). Time to care: Unpaid and underpaid care work and the global inequality crisis. Nairobi: Oxfam International.

Frankiewicz, B. (2020). 5 ways we lack gender balance in the workplace. World Economic Forum. https://www. weforum.org/agenda/2020/01/5-ways-companies-canprogress-more-women-intoleadership-roles/. Retrieved Jan 15, 2021.

Greenstein, T. N. (2000). Economic dependence, gender, and the division of labor in the home: A replication and extension. Journal of Marriage and Family, 62(2), 322-335.

Judith,T \& Lippe, T. \& ChloeTai, Tsui-o. (2011). The Happy Homemaker: Married Women's Well-Being in Cross-National Perspective. Social Forces - SOC FORCES. 90. 111-132. 10.2307/41682634.

Manocha, A., Kumari, L, (2020) QUALITATIVE RESEARCH ON HOMEMAKERS FOR IMPACT ANALYSIS OF COVID 19 ON THE PSYCHOLOGICAL STATE THROUGHOUT LOCKDOWN IN JABALPUR CITY IJCRT | Volume 8, Issue 6 June 2020 | ISSN: 2320-28820 OECD. (n.d.). OECD.Stat. Employment: Time spent in paid and unpaid work, by sex. Retrieved July 3, 2020, from https://stats.oecd.org/index.aspx?queryid=54757. 